\title{
Chemical Composition and Biological Significance of Thymol as Antiparasitic
}

\author{
Wafaa M. Hikal ${ }^{1,2^{*}}$, Kirill G. Tkachenko3 ${ }^{3}$, Hussein A. H. Said-Al Ahl ${ }^{4}$, Hoda Sany ${ }^{5}$, Ali S. Sabra4, \\ Rowida S. Baeshen1, Amra Bratovcic 6
}

\author{
${ }^{1}$ Department of Biology, Faculty of Science, University of Tabuk, Tabuk, KSA \\ ${ }^{2}$ Water Pollution Research Department, Environmental Research Division, National Research Centre, Giza, Egypt \\ ${ }^{3}$ V. L. Komarov Botanical Institute of the Russian Academy of Sciences, Saint Petersburg, Russia \\ ${ }^{4}$ Medicinal and Aromatic Plants Research Department, National Research Centre, Giza, Egypt \\ ${ }^{5}$ Department of Botany (Plant Physiology Section), Faculty of Agriculture, Cairo University, Giza, Egypt \\ ${ }^{6}$ Department of Physical Chemistry and Electrochemistry, Faculty of Technology, University of Tuzla, Tuzla, \\ Bosnia and Herzegovina \\ Email: *wafaahikal@gmail.com
}

How to cite this paper: Hikal, W.M., Tkachenko, K.G., Said-Al Ahl, H.A.H., Sany, H., Sabra, A.S., Baeshen, R.S. and Bratovcic, A. (2021) Chemical Composition and Biological Significance of Thymol as Antiparasitic. Open Journal of Ecology, 11, 240-266.

https://doi.org/10.4236/oje.2021.113018

Received: January 29, 2021

Accepted: February 28, 2021

Published: March 3, 2021

Copyright $\odot 2021$ by author(s) and Scientific Research Publishing Inc. This work is licensed under the Creative Commons Attribution International License (CC BY 4.0).

http://creativecommons.org/licenses/by/4.0/

\begin{abstract}
Thymol is one of the most important phytochemical components because of its pharmacological and bioactive potential effects. This review focuses particularly on thymol as an alternative natural antiparasitic with potential use in the pharmaceutical industry. This is in line with the preferences of the natural products for treatment being safer and without side effects. The biosynthesis pathways of thymol and carvacrol have been discussed, and mechanism of action of thymol on parasites. Studies on thymol confirmed the activity of thymol as anti-parasite against anthelmintic, Trypanosoma ssp., Toxoplasma gondii, Leishmania spp., Plasmodium falciparum, Giardia duodenalis, Eimeria ssp., Cryptosporidium baileyi and Cryptosporidium galli.
\end{abstract}

\section{Keywords}

Thymol, Chemical Composition, Biological Activity, Antiparasitic

\section{Introduction}

A pathogen parasite is an organism that lives on the host organism causing harm and derives sustenance from its host, called medical parasitology. Parasitic disease is a type of infectious disease caused by parasites including parasitic protozoa, parasitic helminths (worms), and those arthropods that directly cause disease or act as vectors of various pathogens (ectoparasites). The diseases caused by these parasites constitute major human health problems throughout the 
world, and sometimes the human infections caused by parasites can be fatal. Parasitic diseases also pose a threat to human life and health in developing countries in particular. Among the important tropical diseases are malaria, schistosomiasis, lymphatic filariasis, onchocerciasis, leishmaniasis, African trypanosomiasis, and chagas disease [1] [2] [3].

Currently, parasitic disease is still prevalent and a threat to human health. Therefore, infection with parasitic diseases is one of the challenges facing countries and scientists and the accurate diagnosis is of great importance and the first step to relieve the sufferings. The countries take great efforts to preserve human health by eliminating parasitic diseases such as schistosomiasis, malaria, filariasis, black fever, and ancylostomiasis in some countries, and many governments have achieved great success in controlling the prevalence of parasitic diseases jointly enacted by the United Nations Children's Fund, United Nations Development Program, World Bank and World Health Organization. Parasitic infections are occurring in all world areas, and the most parasitic infections are more prevalent in tropical countries [1] [2] [3].

However, treating diseases and eliminating the pathogen is still a dominant requirement throughout the ages in order to preserve the health of humans, animals, and plants. Thus, the discovery of new drugs is urgent that led to attention on the search for natural compounds as drugs due to the resistance of some parasites to the synthetic/chemical drugs [4]. For this, the use of phytotherapy has attracted interest from many scientists all over the world due to its biological activities variation related to the variability of their chemical composition, which is in turn influenced by genetic and environmental factors [5]. Note that the use of plants for treatment and other purposes dates back to the emergence of humanity, where it plays an important role in traditional medicine and drug development, including the use of essential oils extracted from medicinal plants [1] [6].

Essential oils are one of the principal fractions of chemical substances found in medicinal plants [7]. Terpenoids and phenylpropanoids are the main chemical compounds found in essential oil, that are widely used as bioactive molecules for many purposes such as biology, agronomy, medicine, and pharmaceutical sciences [8] [9] [10].

Among the prominent uses of essential oil, where it is included in the pharmaceutical industries and it has multiple medicinal uses as an anti-cancer, antitumor, antioxidant activity, antihelmintic, antivirus, antimicrobial, parasiticidal and also, insecticidal, larvicidal, and others as well as activity against diseases vectors [11]-[16]. Examples of some studies confirmed the activity of volatile oil as anti-parasite against intestinal parasites, such as Blastocystis hominis, Entamoeba hartmanni, Endolimax nana, Eimeria tenella, and Pediculus humanus capitis [17] [18] [19]. It is known that the biological activity of volatile oils is due to the synergism between their compounds or for the activity of each component separately [10]. Behnia et al. [20] concluded that, the antiamoebic effects of Thymus vulgaris essential oil against Entamoeba histolytica. Also, Hikal and Said-Al Ahl [14] showed that Plectranthus amboinicus essential oil has an- 
ti-Acanthamoeba activity. These effects are attributable to the main components of the essential oils such as thymol [14] [21]. In this reference paper, we will investigate researches that dealt with the role of thymol its anti-parasite effects.

\section{Plant Sources of Thymol}

Herbs of the Labiatae family, are among the most common families that contain thymol in their essential oil and Thymus vulgaris is one of the most popular plants containing thymol. The quality of thyme essential oil is attributable to thymol. Apart from Thymus vulgaris, several important Thymus species have been reported for thymol sources. As shown in Table 1, medicinal herbs and their plant families and the percentage of thymol in the volatile oil produced by these plants.

\section{Chemical Structure of Thymol}

Thymol (2-Isopropyl-5-methylphenol) is a naturally occurring phenol monoterpene derivative of cymene and isomer of carvacrol (Figure 1 and Figure 2).

There are many potential therapeutic uses of thymol for the treatment of disorders affecting the respiratory [54], nervous [55], and cardiovascular [56] systems, also thymol exhibits antimicrobial, antioxidant, anticarcinogenic, anti-inflammatory, and antispasmodic activities, as well as a potential as a growth enhancer and immunomodulator [57] as well as a potential as a growth enhancer and immunomodulator [58]. Moreover, the application of thymol for its antiparasitic properties has also been reported [57]. Besides, thymol was widely used to treat several helminth infections in man during [59].

In 2008, Wink [60], (Besides, thymol was widely used to treat several helminth infections in man during) has reported the mechanism of action of thymol indicating that thymol causes damage to cell function and structure due to its being highly lipophilic. Thymol may be easily absorbed by the cell membrane, thus causing destabilization of the phospholipid bilayer. It can alter the permeability of the outer and inner mitochondrial membranes of eukaryotic cells, leading to<smiles>Cc1ccc(C(C)C)c(O)c1</smiles>

Thymol<smiles>Cc1ccc(C(C)C)cc1O</smiles>

Carvacrol

Figure 1. Structure of thymol and carvacrol. 
Table 1. Some medicinal herbs containing thymol.

\begin{tabular}{|c|c|c|}
\hline Family & Plant species & Reference \\
\hline & Thymus vulgaris & {$[22]$} \\
\hline & Thymus musilii & {$[23]$} \\
\hline & Thymus zygis, Thymus hyemalis; Thymus glandulosus & {$[24]$} \\
\hline & Thymus lanceolatus & {$[25]$} \\
\hline & Thymus daenensis & {$[26]$} \\
\hline & Thymus capitatus & {$[27]$} \\
\hline & Thymus satureioides subsp. pseudomastichina & {$[28]$} \\
\hline & Thymus serpyllum & {$[29]$} \\
\hline & Thymus spinulosu; Thymus longicaulis subsp. longicaulis & {$[30]$} \\
\hline & Thymus ciliatus, Thymus pallidus & {$[31]$} \\
\hline & Thymus broussonetii; Thymus zygis & {$[32]$} \\
\hline & Thymus maroccanus; Thymus satureoides & {$[33]$} \\
\hline \multirow[t]{14}{*}{ Lamiaceae } & Monarda fistulosa; Monarda didyma & {$[34]$} \\
\hline & Monarda punctata & {$[35]$} \\
\hline & Monarda citriodora & {$[36]$} \\
\hline & Monarda bradburiana & {$[37]$} \\
\hline & Origanum vulgare & {$[38]$} \\
\hline & Origanum syriacum & [39] \\
\hline & Origanum compactum & {$[40]$} \\
\hline & Plectranthus amboinicus & {$[41][42]$} \\
\hline & Marrubium vulgare & {$[43]$} \\
\hline & Satureja montana & {$[44]$} \\
\hline & Satureja spicigera; Satureja intermedia; Satureja mutica & {$[45]$} \\
\hline & Satureja sahendica & {$[46]$} \\
\hline & Zataria multiflora & {$[47]$} \\
\hline & Trachyspermum ammi & {$[4]$} \\
\hline \multirow[t]{3}{*}{ Apiaceae } & Oliveria decumbens & {$[5]$} \\
\hline & Lagoecia cuminoides & {$[48]$} \\
\hline & Lippia multiflora & {$[49]$} \\
\hline \multirow[t]{2}{*}{ Verbenaceae } & Lippia gracilis & {$[50]$} \\
\hline & Lippia sidoides & {$[51]$} \\
\hline Asteraceae & Baccharis grisebachii; Centipeda minima & {$[52]$} \\
\hline Scrophulariaceae & Euphrasia rosstkoviana & {$[53]$} \\
\hline
\end{tabular}

apoptotic effects. Likewise, thymol may inhibit enzymes involved in the protozoal metabolism, such as the ubiquitous enzyme dihydro folate reductase, which catalyzes the NADPH-dependent reduction of dihydrofolate to tetrahydrofolate, 


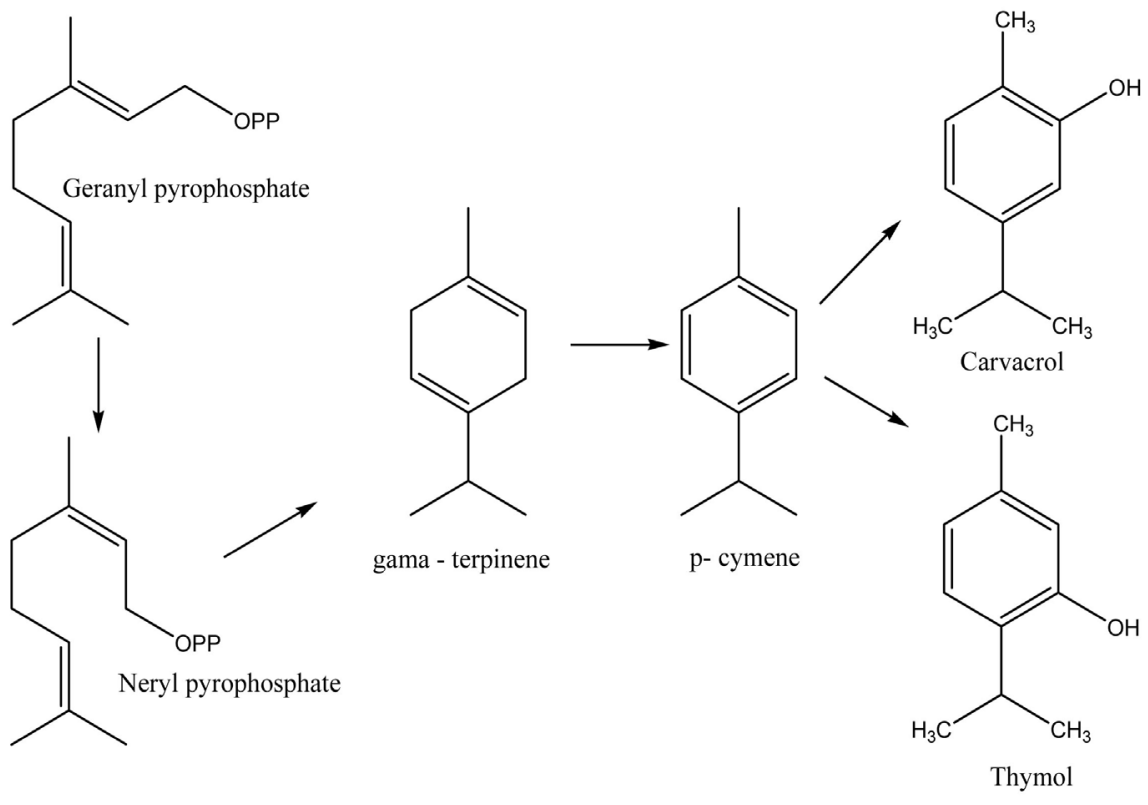

Figure 2. General biosynthesis pathways of aromatic monoterpenes thymol and carvacrol.

a precursor of cofactors required for the biosynthesis of purines, deoxythymidine triphosphate (dTTP), and several amino acids. Its inhibition results in a depletion of the folate pools, leading to the arrest of cell proliferation and cell death. In addition, they interact directly on the synthesis and activity of ATPase, and increase the overall permeability of the cytoplasmic membrane leading to induced cell death by processes associated with the loss of osmoregulation (e.g., leakage of ATP, potassium, and phosphate ions from the parasite).

\section{Thymol Active against Trypanosoma cruzi}

Trypanosoma cruzi parasite causes Chagas disease, also known as American trypanosomiasis, is a potentially life-threatening illness. An estimated 6 to 7 million people worldwide are infected with $T$. cruzi [61].

Trypanosoma cruzi infection is mostly transmitted when humans come into contact with feces and/or urine of infected blood-sucking triatomine bugs (vector-borne transmission). The parasites enter the body by skin break, the eyes or the mouth, or by consumption of food that has been contaminated with waste from infected triatomine bugs, causing outbreaks or oral transmission. Chagas disease can be also transmitted through blood or blood product transfusion from infected donors, during pregnancy or childbirth; and also organ transplantation from infected donors [61].

Symptoms are skin lesion or a purplish swelling of the lids of one eye (the so-called Romaña sign), fever, headache, enlarged lymph glands, pallor, muscle pain, difficulty in breathing, swelling, and abdominal or chest pain, cardiac disorders, experience digestive, neurological or mixed disorders. In later infection can lead to sudden death principally due to heart arrhythmia or heart failure 
caused by the destruction of the heart muscle and its nervous system [61]. Benznidazole and nifurtimox are two treatments for chagas disease, but they should not be taken by pregnant women or by people with kidney or liver failure. Nifurtimox is also should not be taken for people with a background of neurological or psychiatric disorders [61].

Thymol compound, the major constituent of Thymus vulgaris essential oil has trypanocidal activity against Trypanosoma cruzi. Santoro et al. [62] showed effective thymol against epimastigotes and trypomastigote lysis of Trypanosoma cruzi, and added that thymol showed an $\mathrm{IC}_{50} / 24 \mathrm{~h}$ value of $62 \mu \mathrm{g} / \mathrm{mL}$ for epimastigotes and an $\mathrm{IC}_{50} / 24 \mathrm{~h}$ and value of $53 \mu \mathrm{g} / \mathrm{mL}$ for trypomastigotes. Moreover, thymol gave similar results to those obtained in vitro from treatment with the reference drug (benznidazole). Santoro et al. [62] explained that thymol permeates the cell membrane and kills the parasites by affecting cytoplasmic metabolic pathways or organelles, and not by compromising the parasite membrane integrity.

The result of another study on thymol as a major compound in the essential oil of Lippia spp., and Thymus vulgaris indicated that thymol had an effective against epimastigotes from Trypanosoma cruzi with $\mathrm{IC}_{50}$ values in the range of 5.5 to $32.2 \mu \mathrm{g} / \mathrm{mL}$ and thymol $\left(\mathrm{IC}_{50} 3.2 \pm 0.4 \mu \mathrm{g} / \mathrm{ml}\right)$ was active against intracellular amastigotes of $T$. cruzi-infected Vero cells [63].

The same result was observed by Borges et al. [64], where that Lippia sidoides essential oil, which contains thymol (78.4\%) as the main constituent has efficacy against disease epimastigote forms ( $\mathrm{IC}_{50}$ values of $21.3,26.2$, and $28.9 \mu \mathrm{g} / \mathrm{mL}$, respectively) from Trypanosoma cruzi. Juan et al. [65] confirmed that thymol exhibits anti-Trypanosoma-cruzi effect in vivo, when treating infected albino mice with thymol at a dose of $\mathrm{mg} / \mathrm{kg} /$ day.

\section{Thymol with Anti-Trypanosoma brucei Activity}

Human African trypanosomiasis, also known as sleeping sickness, is a vector-borne parasitic disease. It is caused by infection with protozoan parasites belonging to the genus Trypanosoma. They are transmitted to humans by tsetse fly (Glossina genus) bites which have acquired their infection from human beings or from animals harbouring human pathogenic parasites, the disease is considered fatal without treatment [66].

Human African trypanosomiasis takes two forms: Trypanosoma brucei gambiense and Trypanosoma brucei rhodesiense. Trypanosoma bruceigambiense form currently accounts for $98 \%$ of reported cases of sleeping sickness and causes a chronic infection. When more evident symptoms emerge, the patient is often already in an advanced disease stage where the central nervous system is affected. Trypanosoma brucei rhodesiense form represents under $2 \%$ of reported cases and causes an acute infection. Animals can host the human pathogen parasites, which domestic and wild animals are an important reservoir. Animals can also be infected with Trypanosoma brucei gambiense and probably act as a reservoir to a lesser extent [66]. 
There are more ways in which people are infected: bite of an infected tsetse fly, mother-to-child infection: the trypanosome can cross the placenta and infect the fetus, pricks with contaminated needles, through sexual contact. Symptoms appear in two stages; the first stage, the trypanosomes multiply in subcutaneous tissues, blood, and lymph. This is also called the haemo-lymphatic stage, which entails bouts of fever, headaches, enlarged lymph nodes, joint pains, and itching. In the second stage, the parasites cross the blood-brain barrier to infect the central nervous system. This is known as the neurological or meningo-encephalic stage. In general, this is when more obvious signs and symptoms of the disease appear: changes of behaviour, confusion, sensory disturbances, and poor coordination. Disturbance of the sleep cycle, which gives the disease its name, is an important feature. Without treatment, sleeping sickness is considered fatal although cases of healthy carriers have been reported [66]. The type of treatment depends on the form of the disease and the disease stage. Six different drugs are used for the treatment of sleeping sickness. Pentamidine is used for the treatment of the first stage of T.b. gambiense sleeping sickness and Suramin is used for the treatment of the first stage of T.b. rhodesiense. Melarsoprolis used for the treatment of the second stage of both gambiense and rhodesiense infections [66].

Costa et al. [67], have reported that thymol which is the constituent of both Lippia graveolens and Origanum virens essential oils showed high efficacy against Trypanosoma brucei. Also, Kpoviessi et al. [68], found that the volatile oil of Ocimum gratissimum extracted from the seeds, leaves and stem contains the thymol compound which was effective as anti-Trypanosoma brucei $\left(\mathrm{IC}_{50}\right.$ of $27.23 \pm 3.74 \mu \mathrm{g} / \mathrm{mL}$ ). The same result was obtained by [69]. They announced that the treatment with thymol $\left(\mathrm{IC}_{50}\right.$ of $\left.22.86 \mu \mathrm{g} / \mathrm{mL}\right)$ showed efficacy against Trypanosoma brucei.

Tasdemir et al. [70], proved that thymol compound has trypanocidal (antitrypanosomal) activity against Trypanosoma brucei rhodesiense, with $\mathrm{IC}_{50}$ values of $110 \mathrm{ng} / \mathrm{mL}$. Although carvacrol is the main component (70.6\%) and thy$\mathrm{mol}(1.8 \%)$, in the volatile oil of Origanum onites. However, thymol gave a better result than carvacrol in vitro against $T$. brucei with IC $_{50}$ values of 11.3 and $22.9 \mu \mathrm{g} / \mathrm{mL}$ [69]. Anti-Trypanosoma cruzi activity also was reported [62] [71]. Thymol exhibits high antioxidant activity, which could protect the protozoans and prevent the action of oxidative stress caused by the host's cellular immune response [72].

\section{Thymol Active against Toxoplasma}

Toxoplasmosis is caused by Toxoplasma gondii. Toxoplasma gondii, an intracellular coccidian protozoan parasite is endemic throughout most of the world. Risk is higher in developing and tropical countries, especially when people eat undercooked meat or shellfish, drink untreated water, or have extensive soil exposure. Congenital transmission can also occur if a woman is infected during pregnancy, also through ingestion of soil, or food contaminated with cat feces, and contaminated blood transfusion and organ transplantation [73]. 
Symptoms may include influenza-like symptoms or a mononucleosis syndrome with prolonged fever, lymphadenopathy, elevated liver enzymes, lymphocytosis, and weakness. Rarely, chorioretinitis or disseminated disease can occur in immunocompetent people. In severely immunocompromised people, severe and even fatal encephalitis, pneumonitis, and other systemic illnesses can occur. Infants with congenital toxoplasmosis are often asymptomatic, but eye disease, neurologic disease, or other systemic symptoms can occur, and learning disabilities, cognitive deficits, or visual impairments may develop later in life [73].

Treatment is reserved for acutely infected pregnant women and those with severe disease or who are immunocompromised. The recommended regimen includes pyrimethamine, sulfadiazine, and leucovorin (folinic acid). Alternative treatment regimens include clindamycin, atovaquone, and azithromycin [73].

The principal components of the Satureja khuzestanica essential oil are carvacrol, thymol, p-cymene, $\beta$-caryophyllene, linalool [74] [75]. Mahmoudvand et al. [76] showed that Satureja khuzestanica essential oil has anti-toxoplasmosis against Toxoplasma gondii. However, regarding the mechanism of action of phenolic compounds, such as carvacrol and thymol, it has been shown that these compounds are proton exchangers, thus dropping the gradient through the cytoplasmic wall. They cause the breakdown of proton-motrice force and reduction of the ATP pool, leading finally to cell death [77].

Thymol presents intriguing anti-Toxoplasma effects perhaps by acting on free radicals arising from tissue damage caused by the disease. T. gondii infections can cause devastating disease in immunosuppressed patients and through congenital infection of newborn babies [78]. They recommended the thymol as an anti-Toxoplasma gondii in vivo and highlight its safe use in animals.

\section{Thymol Active against Leishmaniasis}

The leishmaniases are a group of diseases caused by protozoan parasites from more than 20 Leishmania species. These parasites are transmitted to humans by the bite of an infected female phlebotomine sandfly. There are four main forms of the disease: cutaneous leishmaniasis, visceral leishmaniasis, also known as kala-azar, mucocutaneous leishmaniasis, and post-kala-azar dermal leishmaniasis. Cutaneous leishmaniasis is the most common form, visceral leishmaniasis is the most severe form and can be fatal if untreated, and mucocutaneous leishmaniasis is the most disabling form of the disease. Most people who become infected with the parasite do not develop any symptoms during their lifetime. Today, more than 1 billion people live in areas endemic for leishmaniasis and are at risk of infection. An estimated 30,000 new cases of visceral leishmaniasis and more than 1 million new cases of cutaneous leishmaniasis occur annually. Additionally, leishmaniasis can be classified as anthroponotic or zoonotic depending on whether the natural reservoir of the parasite is human or animal [79].

Cutaneous leishmaniasis usually produces ulcers on the exposed parts of the body, such as the face, arms, and legs. There may be many lesions, which can 
cause serious disability. When the ulcers heal, they invariably leave permanent scars, especially for women and girls. Visceral leishmaniasis is characterized by irregular bouts of fever, substantial weight loss, swelling of the spleen and liver and serious anaemia. If the disease is not treated, the fatality rate can be as high as $100 \%$ within 2 years. Mucocutaneous leishmaniasis produces lesions that can partially or totally destroy the mucous membranes of the nose, mouth and throat cavities and surrounding tissues. Post-kala-azar dermal leishmaniasis, a complication of visceral leishmaniasis, is characterized by a discoloured (hypopigmented) flat skin (macular) rash, combined with some slightly elevated (maculopapular) or elevated (nodular) rash, usually in patients who have recovered from visceral leishmaniasis. Post-kala-azar dermal leishmaniasis heals spontaneously in most cases in Africa but rarely in patients in India [79]. Regardless of the causative Leishmania species, antileishmanial treatment cannot provide a sterile cure, and the parasite remains in the human body and can cause a relapse when there is immunosuppression. Treatment is complex and should be administered by highly experienced health personnel. Most antileishmanial medicines are injectable [79].

Several studies indicated that thymol has anti-Leishmania in vivo, including Tisserand and Balacs's study [80] and his recognized the active effect of thymol against Leishmania amazonensis promastigote. Likewise, Silva et al. [81] confirmed from their study that thymol had antileishmanial agents against promastigote forms of Leishmania amazonensis.

Other studies carried out by [82] [83] showed that thymol had activity against promastigotes forms of Leishmania chagasi with $\mathrm{IC}_{50}$ values of $9.8 \mu \mathrm{g} / \mathrm{mL}$. Also, Xavier et al. [84] demonstrated that thymol had activity against promastigotes forms of Leishmania amazonensis. In a recent study, Tasdemir et al. [70], reported that thymol had a higher leishmanicidal effect than carvacrol.

Robledo et al. [85] concluded the anti-Leishmania panamensis of thymol. Oliveira et al. [86] concluded that thymol extracted from Lippia sidoides has anti-Leishmania chagasi. However, De Medeiros et al. [87] showed that thymol extracted from Lippia sidoides essential oil has anti-Leishmania amanuensis. Similarly, Farias-Junior et al. [83] and Morales et al. [88], announced the same result that thymol has anti-Leishmania chagasi activity. Whereas De Morais et al. [89] found the leishmanicidal activity of thymol against both promastigotes and amastigotes of Leishmania chagasi.

Youssefi et al. [90] reported the leishmanicidal effects of thymol against Leishmania chagasi promastigotes ( $\mathrm{IC}_{50}$ values $7.2 \mu \mathrm{g} / \mathrm{mL}$ ). They added that thymol was the most effective and the safest metabolite with the lowest side effects on the hamster liver infected with Leishmania chagasi comparing with carvacrol and linalool. Overall, thymol and carvacrol are highly promising candidates for the development of effective and safe drugs in the fight against leishmanial. Besides, thymol at 10,5 , and $2.5 \mu \mathrm{g} / \mathrm{mL}$ was highly effective against Leishmania infantum. However, thymol and carvacrol, with $\mathrm{IC}_{50}$ (90) values of $7.2 \mu \mathrm{g} / \mathrm{mL}(16.4 \mu \mathrm{g} / \mathrm{mL})$ and $9.8 \mu \mathrm{g} / \mathrm{mL}(18.2 \mu \mathrm{g} / \mathrm{mL})$, respectively, showed 
promising growth inhibition on $L$. infantum promastigotes [90].

In vivo, Jain and Jain [91] showed the anti-leishmanial activity of thymol led to a decrease in the number of liver amastigotes in histopathological samples in comparison with the control group. Furthermore, thymol had a stronger inhibitory effect on the in vitro and in vivo growth of Leishmania infantum compared to carvacrol. Moreover, the significance of thymol as anti-leishmanial activity alone or in combination with standard drugs (e.g., glucantime, amphotericin B) was promising and can also be used to improve efficacy in leishmaniasis treatment and to reduce the emergence of drug resistance and side effects.

Satureja bakhtiarica essential oil containing thymol had a potential effect against leishmaniasis higher than glucantime drug [92]. While glucantime inhibited only $27 \%$ of parasites at a concentration of $750 \mu \mathrm{g} / \mathrm{mL}$, all promastigotes were killed in the presence of the essential oil at this concentration. Furthermore, the essential oil can kill the parasites even at a concentration of $150 \mu \mathrm{g} / \mathrm{mL}$ during the first incubation times $(24-48 \mathrm{~h}$ ), but this was not observed for glucantime. The higher effect of essential oil compared to glucantime as anti-Leishmania is attributable to the phenolic compounds thymol and p-cymene components in essential oil.

Moreover, Escobar et al. [63] found that thymol component found in Lippia origanoides essential oil had an $\mathrm{IC}_{50}$ of $4.4 \mu \mathrm{g} / \mathrm{ml}$ against Leishmania chagasi promastigotes and showed no toxicity in mammalian cells. Also, thymol isolated from Lippia sidoides essential oil showed anti-Leishmania action against promastigotes and amastigotes of Leishmania amazonensis [93] [94].

\section{Thymol with Antimalarial Potential}

Malaria is a major international public health problem. 91 countries reported an estimated 216 million infections and 445,000 deaths in 2016, according to the World Health Organization (WHO) World Malaria Report 2017. Malaria in humans is caused by protozoan parasites of the genus Plasmodium: Plasmodium falciparum, $P$. vivax, $P$. ovale, or $P$. malariae. In addition, $P$. knowlesi, a parasite of old world (Eastern Hemisphere) monkeys, has been documented as a cause of human infections and some deaths in Southeast Asia. Plasmodium species are transmitted by the bite of an infective female Anopheles mosquito. Occasionally, transmission occurs by blood transfusion, organ transplantation, needle sharing, nosocomially, or from mother to fetus [95].

Malaria is characterized by fever and influenza-like symptoms, including chills, headache, myalgias, and malaise; these symptoms can occur intermittently. In severe disease, seizures, mental confusion, kidney failure, acute respiratory distress syndrome, coma, and death may occur. Suspected or confirmed malaria, especially $P$. falciparum, is a medical emergency requiring urgent intervention, as clinical deterioration can occur rapidly and unpredictably [95].

Malaria can be treated effectively early in the course of the disease, but a delay of therapy can have serious or even fatal consequences. Specific treatment options depend on the species of malaria, the severity of infection, the likelihood of 
drug resistance (based on where the infection was acquired), and the patient's age and pregnancy status [95].

Tasdemir et al. [70] showed that thymol has antimalarial potential-plasmocidal (P. falciparum) potentials. Also, proved that carvacrol (70.6\%), is the main component of the Origanum onites essential oil whereas thymol, which exists therein with much lower abundance (1.8\%), exhibited in vitro antimalarial potential-plasmocidalequal to carvacrol.

Previous studies carried out by Mota et al. [96] confirmed the effectiveness of thymol as an anti-malaria in vitro with $\mathrm{IC}_{50}$ value of $4.5 \mu \mathrm{g} / \mathrm{mL}$. Also, Fujisaki et al. [97] concluded that thymol component in oregano essential oil showed in vitro antimalarial activity against $P$. falciparium with an $\mathrm{IC}_{50}$ value of $10 \mu \mathrm{g} / \mathrm{mL}$. Moreover, the activity of thymol is attributed to the characteristic feature of the phenolic hydroxyl group, which may be more acidic than carvacrol, and hence more active, due to the presence of a system of delocalized electrons [98] [99].

Satureja thymbra essential oil is rich in thymol, showed high in vitro anti-plasmodial activity against Plasmodium falciparum [100], causing enzyme (plasmepsins) inhibition at a concentration very close to that needed for killing the parasite. Also, Mota et al. [96] mentioned that, thymol, the main component of Lippia sidoides essential oil exhibited antimalarial activity against Plasmodium berghei in mice and Plasmodium falciparum in vitro.

Origanum compactum essential oil rich in thymol showed anti-plasmodial activity in vitro [101]. While, Thymus vulgaris, Thymus serpyllus, and Myrtus communis essential oils rich in thymol showed to be repellent against Aedes, Anopheles and Culex mosquitoes [102] [103]. However, thyme essential oil is patented for anophelifuge activity [104]. Several previous studies have demonstrated the anti-malarial efficacy of the volatile oils of Thymus transpicatus, Thymus vulgaris and Myrtus communis rich in thymol as larvicidal activity against Anopheles [100] [105] [106] [107].

\section{Thymol against Giardiasis}

The anaerobic protozoan parasite Giardia duodenalis (formerly known as $G$. lamblia or G. intestinalis) is endemic worldwide. Giardia is transmitted via the fecal-oral route. Its low infectious dose, protracted communicability, and moderate chlorine tolerance make Giardia ideally suited for transmission through drinking and recreational water. Transmission also occurs through contact with feces (for example, when providing direct patient care or during sexual activity), eating contaminated food, or contact with fecally contaminated surfaces [108].

Many infected people are asymptomatic, though if symptoms develop, they typically develop 1 - 2 weeks after exposure and generally resolve within $2-4$ weeks. Symptoms include diarrhea (often with foul-smelling, greasy stools), abdominal cramps, bloating, flatulence, fatigue, anorexia, and nausea. Sometimes upper gastrointestinal symptoms are prominent. Weight loss may occur over time. Fever and vomiting are uncommon. Reactive arthritis, irritable bowel syn- 
drome, and other chronic symptoms sometimes occur after infection with Giardia. Effective treatments include metronidazole, tinidazole, and nitazoxanide [108].

Machado et al. [109] observed that carvacrol, thymol, and eugenol had antigiardial activity against Giardia lamblia trophozoite. Also, Thymbra capitata, Origanum virens, Thymus zygis subsp. Sylvestris and Lippia graveolens essential oils rich in thymol inhibited the growth of Giardia lamblia. Moreover, Lippia graveolens had great potential as treatment agents for giardiasis caused by Giardia lamblia and Thymus capitata oil was the most active [110].

\section{Thymol against Cryptosporidiosis}

Among the many protozoan parasites in the genus Cryptosporidium, Cryptosporidium hominis and C. parvum cause $>90 \%$ of human infections. Cryptosporidiosis is endemic worldwide, and the highest rates are found in developing countries [111].

Cryptosporidium is transmitted via the fecal-oral route. Its low infectious dose, prolonged survival in moist environments, protracted communicability, and extreme chlorine tolerance make Cryptosporidium ideally suited for transmission through contaminated drinking or recreational water (such as the swimming pool). Transmission can also occur through eating contaminated food, through contact with infected animals (particularly preweaned bovine calves) or people (for example, when providing direct care or during oral-anal sex), or through contact with fecally contaminated surfaces [111].

Symptoms (most commonly, profuse, watery diarrhea) begin within 2 weeks (typically 5 - 7 days) after infection and are generally self-limited. Other symptoms can include abdominal pain, flatulence, urgency, nausea, vomiting, and low-grade fever. In immunocompetent people, symptoms typically resolve within 2 - 3 weeks; patients may experience a recurrence of symptoms after a brief period of recovery and before complete symptom resolution. Extraintestinal cryptosporidiosis (in the biliary or respiratory tract and rarely the pancreas) has been documented in children and immunocompromised hosts [111].

Tanghort et al. [112] recommended Thymol for fighting cryptosporidiosis (Cryptosporidium baileyi and Cryptosporidium galli) due to its destructive effect on oocysts at very low concentrations. There are well-known drugs against parasites such as albendazole. Currently, the only FDA drug approved for Crypto is nitazoxanide, but there are limitations and recommended thymol as anticreptospiridium [113].

\section{Thymol against Anthelmintic}

A large part of the world's population is infected with 1 or more of these helminths, and the prevalence is highest in tropical and subtropical countries where water supplies and sanitation are poor. Ascaris lumbricoides (roundworm), Ancylostoma duodenale (hookworm), Necator americanus (hookworm), and Tri- 
churis trichiura (whipworm) are helminths (parasitic worms) that infect the intestine and are transmitted via contaminated soil. Eggs are passed in feces from an infected person. Hookworm eggs are not infective-the eggs must hatch and release larvae that need to mature in the soil before they become infective. Infection with roundworm and whipworm occurs when eggs in soil have become infective and are ingested. Hookworm infection usually occurs when larvae penetrate the skin of people walking barefoot on contaminated soil. However, the hookworm Ancylostoma duodenale can also be transmitted when larvae are ingested [114].

Most infections are asymptomatic, especially when few worms are present. Pulmonary symptoms (Löffler syndrome) occur in a small percentage of patients when roundworm larvae pass through the lungs. Löffler syndrome is associated with fever and marked eosinophilia. Roundworms can also cause intestinal discomfort, obstruction, and impaired nutritional status. Hookworm infection can lead to anemia due to blood loss and chronic protein deficiency. Whipworm infection can cause chronic abdominal pain, diarrhea, blood loss, dysentery, and rectal prolapse. The most commonly used drugs for treatment are albendazole and mebendazole [114].

\subsection{Thymol against Ascaris}

Ascaris lumbricoides is the most prevalent soil-transmitted helminth infection of human beings worldwide. Chemotherapy with synthetic anthelmintics such as albendazole, mebendazole, and pyrantel pamoate is the current method of treatment; however, the emergence of anthelmintic resistance could substantially decrease the efficacy of such treatments. Additionally, benzimidazoles are not recommended for pregnant women or children under age one [115]. Hence, Kaplan et al. [115] conducted a study on the effect and efficacy of two microencapsulated, plant-based essential oil blends such as a-pinene, linalyl acetate, p-cymene, and thymol octanoate on helminths. The study concluded that a-pinene, linalyl acetate, p-cymene, and thymol octanoate promise as a daily supplement to reduce infection burdens of soil-transmitted helminths in both pigs and human beings.

\subsection{Thymol against Echinococcus Tapeworms}

Echinococcosis is a parasitic disease caused by infection with tiny tapeworms of the genus Echinococcus. Echinococcosis is classified as either cystic echinococcosis or alveolar echinococcosis [116].

Cystic echinococcosis, also known as hydatid disease, is caused by infection with the larval stage of Echinococcus granulosus, found in dogs (definitive host) and sheep, cattle, goats, and pigs (intermediate hosts). Although most infections in humans are asymptomatic, cystic echinococcosis causes harmful, slowly enlarging cysts in the liver, lungs, and other organs that often grow unnoticed and neglected for years [116]. 
Cystic echinococcosis is caused by infection with the larval stage of Echinococcus granulosus. It is found in Africa, Europe, Asia, the Middle East, Central and South America, and in rare cases, North America. The parasite is transmitted to dogs when they ingest the organs of other animals that contain hydatid cysts. The cysts develop into adult tapeworms in the dog. Infected dogs shed tapeworm eggs in their feces which contaminate the ground. Sheep, cattle, goats, and pigs ingest tapeworm eggs in the contaminated ground; once ingested, the eggs hatch and develop into cysts in the internal organs. The most common mode of transmission to humans is by the accidental consumption of soil, water, or food that has been contaminated by the fecal matter of an infected dog. Echinococcus eggs that have been deposited in the soil can stay viable for up to a year. The disease is most commonly found in people involved in raising sheep, as a result of the sheep's role as an intermediate host of the parasite and the presence of working dogs that are allowed to eat the offal of infected sheep [116].

Alveolar echinococcosis disease is caused by infection with the larval stage of Echinococcus multilocularis, found in foxes, coyotes, and dogs (definitive hosts). Small rodents are intermediate hosts for E. multilocularis. Although cases of alveolar echinococcosis in animals in endemic areas are relatively common, human cases are rare. Alveolar echinococcosis poses a much greater health threat to people than cystic echinococcosis, causing parasitic tumors that can form in the liver, lungs, brain, and other organs. If left untreated, alveolar echinococcosis can be fatal [116]. Infection with the larval stages is transmitted to people through the ingestion of food or water contaminated with tapeworm eggs [116].

In the past, surgery was the only treatment for cystic echinococcal cysts. Chemotherapy, cyst puncture, and percutaneous aspiration, injection of chemicals and respiration have been used to replace surgery as effective treatments for cystic echinococcosis. However, surgery remains the most effective treatment to remove the cyst and can lead to a complete cure. Some cysts are not causing any symptoms and are inactive; those cysts often go away without any treatment. The treatment of alveolar echinococcosis is more difficult than cystic echinococcosis and usually requires radical surgery, long-term chemotherapy, or both [116].

Albani et al. [117] state that, human alveolar echinococcosis is caused by the fox tapeworm Echinococcus multilocularis and is usually lethal if left untreated. The current strategy for treating human alveolar echinococcosis is surgical resection of the parasite mass complemented by chemotherapy with benzimidazole compounds. They added that combined benzimidazole with thymol treatment exhibited higher treatment efficiency compared with the drugs applied separately against murine experimental alveolar echinococcosis. In such a way thymol would be a useful option for the treatment of human alveolar echinococcosis.

Elissondo et al. [118] concluded that thymol has a clear effect of thymol against Echinococcus granulosus protoscoleces in vitro. Moazeni et al. [119] found that essential oil of Trachyspermum ammi rich in thymol (50.07\%), 
$\gamma$-terpinene (23.92\%) and p-cymene (22.9\%) has effect against Echinococcus tapeworms protoscoleces. They concluded that scolicidal power of Trachyspermum ammi essential oil at a concentration of $3 \mathrm{mg} / \mathrm{mL}$ was $31.34 \%, 35.98 \%$, $45.17 \%$, and $51.58 \%$ after $10,20,30$, and $60 \mathrm{~min}$, respectively. Besides, one hundred percent scolicidal activity was observed with Trachyspermum ammi essential oil at concentration of $10 \mathrm{mg} / \mathrm{mL}$ after $10 \mathrm{~min}$ of exposure. The results of this study revealed that the essential oil of Trachyspermum ammi is rich in thymol, $\gamma$-terpinene and p-cymene, has high scolicidal power and may be used as a natural scolicidal agent.

Elissondo et al. [118] [120] concluded that thymol was affected againstprotoscoleces, microcysts, and cysts of Echinococcus granulosus in vitro. Also Trachyspermum ammi essential oil contains thymol confirmed against protoscoleces of Echinococcus granulosus [119] [121] [122] [123]. In a study on essential oils of Thymus vulgaris rich in thymol and Origanum vulgare rich in thymol and carvacrol on anthelmintic effect, Pensel et al. [124] found an effective effect against protoscoleces and cysts of Echinococcus granulosus. The results showed that thymol had a considerably greater effect than carvacrol. Thymol and essential oils of Thymus vulgaris and Origanum vulgare can induce apoptosis in the cells of protoscoleces [124] [125].

\subsection{Thymol against Haemonchus contortus}

Haemonchus contortus is one of the principal stomach worms of sheep, and infection is characterized by anemia. Gastrointestinal nematode infections have an important negative impact on small ruminant production. Haemonchus contortus is the most economically significant parasite of sheep and goats throughout much of the United States and the world, due to the severity of the parasitism and the emerging anthelmintic resistance. Haemonchosis also affects New World camelids. It is a common cause of death in all these species [126] [127] [128] [129].

The most common clinical signs are failure to thrive and weight loss. As worm burdens increase, more severe signs, such as anemia, hypoproteinemia, submandibular edema (bottle jaw), weakness, and collapse, may develop. Unlike other gastrointestinal nematodes, Haemonchus contortus does not usually cause diarrhea. Due to the nonspecific signs and lack of diarrhea, haemonchosis is often undiagnosed until death. The death can appear suddenly, even though the course of infection may have been prolonged [126] [127] [130].

A major problem facing the sheep industry is resistance to macrolide dewormers, such as ivermectin and moxidectin. Haemonchus contortus has also been resistant to benzimidazoles (e.g., fenbendazole), tetrahydropyrimidines (e.g., pyrantel), and levamisole [126] [127].

Haemonchus contortus is an important gastrointestinal parasite on sheep farms in tropical regions and due to the resistance of Haemonchus contortus against most anthelmintic drugs represents a great economic problem to sheep 
farming and is a major challenge that needs to be overcome. Ferreira et al. [131] found that thymol, the main component in Thymus vulgaris essential oil is the most important compound responsible for the anthelmintic. The in vitro results validated the popular use of $T$. vulgaris oil as an anthelmintic agent against $H$. contortus. Both the essential oil and thymol (50.22\%) were effective against the three main stages of $H$. contortus. The essential oil and thymol were able to inhibit egg hatching by $96.4 \%-100 \%$, larval development by $90.8 \%-100 \%$, and larval motility by $97 \%-100 \%$. The essential oil and thymol completely inhibited the motility of $H$. contortus adults within the first $8 \mathrm{~h}$ of the experiment.

From André and co-workers [132] experience on the effect of thymol and thymol acetate on Haemonchus contortus, they found that thymol $(0.5 \mathrm{mg} / \mathrm{mL})$ and thymol acetate $(4 \mathrm{mg} / \mathrm{mL})$ inhibited larval hatching by $98 \%$ and $67.1 \%$, respectively. Thymol and thymol acetate $(8 \mathrm{mg} / \mathrm{mL})$ inhibited $100 \%$ of larval development. Thymol and thymol acetate $(800 \mu \mathrm{g} / \mathrm{mL})$ reduced the motility of adult worms, by $100 \%$ and $83.4 \%$, respectively. Thymol caused cuticular changes in adult worm teguments. In the acute toxicity test, the $\mathrm{LD}_{50}$ of thymol and thy$\mathrm{mol}$ acetate were $1350.9 \mathrm{mg} / \mathrm{kg}$ and $4144.4 \mathrm{mg} / \mathrm{kg}$, respectively. Thymol and thymol acetate reduced sheep egg count per gram of faeces (epg) by $59.8 \%$ and $76.2 \%$, respectively. In vitro tests, thymol presented better anthelmintic activity than thymol acetate. However, thymol acetate was less toxic and in in vivo test efficacy was similar.

\section{Thymol against Coccidiosis}

Coccidiosis is a disease caused by parasites of the genus Eimeria and Isospora belonging to the phylum Apicomplexa with a complex life cycle, affecting mainly the intestinal tract of many species of mammals and birds, especially chickens. The economic significance of coccidiosis is attributed to decreased animal production (higher feed conversion, growth depression and, increased mortality) and the costs involved in treatment and prevention. Worldwide, the annual costs inflicted by coccidiosis to commercial poultry have been estimated at billions of Euro, stressing the urgent need for more efficient strategies to control this parasite [133].

Symptoms of coccidiosis in chickens (high mortality rates, characteristic intestinal lesions, watery/bloody faeces, etc.). Mortality, morbidity, diarrhoea or bloody faeces, and sub-clinical coccidiosis manifest mainly by poor weight gain and reduced efficiency of feed conversion and gives rise to the highest proportion of the total economic losses [134].

Numerous anticoccidial drugs such as sulphaquinoxaline and nitrofurazone were first approved by the American Food and Drug Administration. Most of the anticoccidial products currently approved in different regions of the world for the prevention of coccidiosis in chickens are amprolium, ethopabate, aprinocid, clopidol, decoquinate, diclazuril, dinitolmide (zoalene), halofuginone, nequinate (methyl benzoate), nicarbazin, robenidine, lasalocid, maduramicin, mo- 
nensin, narasin, narasin + nicarbazin, salinomycin and semduramycin [133]. Teichmann's study and coworkers [135] on parasite Eimeria in the laboratory showed the effectiveness of thymol in relieving the symptoms of the coccidiosis disease when thymol was added to the diet or added with to anticoccidial drug lasalocid.

\section{Conclusion}

Thymol is naturally phytochemical found in a lot of medicinal herbs and widely used in many potential therapeutic uses, to treat several parasite infections. $\mathrm{Nu}$ merous studies conducted on thymol have confirmed its effectiveness as an anti-parasite. Further research on thymol activities is still needed for details and information about the mechanism of action of thymol against parasites and each species separately. In this review, an update of the potential of thymol is active against some neglected diseases. The compiling of this review is intended to know the pathogen that caused parasitic disease and thus to provide the basis for treating the diseases by phytotherapy.

\section{Conflicts of Interest}

The authors declare no conflicts of interest regarding the publication of this paper.

\section{References}

[1] Hikal, W.M. (2020) Parasitic Contamination of Drinking Water and Egyptian Standards for Parasites in Drinking Water. Open Journal of Ecology, 10, 1-21. https://doi.org/10.4236/oje.2020.101001

[2] Hikal, W.M., Said-Al Ahl, H.A.H. and Tkachenko, K.G. (2020) Present and Future Potential of Antiparasitic Activity of Opuntia ficus-indica. Tropical Journal of Natural Product Research, 4, 672-679. https://doi.org/10.26538/tjnpr/v4i10.3

[3] Wang, Y. (2017) Introduction to Parasitic Disease. In: Li, H., Ed., Radiology of Parasitic Diseases, Springer, Dordrecht, 3. https://doi.org/10.1007/978-94-024-0911-6_1

[4] Hikal, W.M. and Said-Al Ahl, H.A.H. (2019) Cysticidal Activity of Trachyspermum ammi Essential Oil against Acanthamoeba Isolates from Dental Clinic and Hospital Water Networks. Pakistan Journal of Zoology, 51, 1799-1806. https://doi.org/10.17582/journal.pjz/2019.51.5.1799.1806

[5] Karami, A., Tahereh Khoshbakht, T., Hassan Esmaeili, H. and Maggi, F. (2020) Essential Oil Chemical Variability in Oliveria decumbens (Apiaceae) from Different Regions of Iran and Its Relationship with Environmental Factors. Plants, 9, 680. https://doi.org/10.3390/plants9060680

[6] Scotti, L., Mendonça Júnior, F.J.P., Silva, M.S. and Scotti, M.T. (2016) Drug Design Applied to Natural Products against Neglected Diseases. In: Gupta, G.K. and Kumar, V., Eds., Chemical Drug Design, De Gruyter, Berlin, 53-86. https://doi.org/10.1515/9783110368826-006

[7] Kamte, S.L.N., Ranjbarian, F., Campagnaro, G.D., Biapa Nya, P.C., Mbuntcha, H., Woguem, V., Womeni, H.M., et al. (2017) Trypanosoma brucei Inhibition by Essential Oils from Medicinal and Aromatic Plants Traditionally Used in Cameroon 
(Azadirachta indica, Aframomum melegueta, Aframomum daniellii, Clausena anisata, Dichrostachys cinerea and Echinops giganteus). International Journal of Environmental Research and Public Health, 14, 737.

https://doi.org/10.3390/ijerph14070737

[8] Benelli, G. and Mehlhorn, H. (2016) Declining Malaria, Rising of Dengue and Zika Virus: Insights for Mosquito Vector Control. Parasitology Research, 115, 1747-1754. https://doi.org/10.1007/s00436-016-4971-Z

[9] Hikal, W.M., Baeshen, R.S. and Said-Al Ahl, H.A.H. (2017) Botanical Insecticide as Simple Extractives for Pest Control. Cogent Biology, 4, Article ID: 1404274. https://doi.org/10.1080/23312025.2017.1404274

[10] Said-Al Ahl, H.A.H., Hikal, W.M. and Mahmoud, A.A. (2017) Essential Oils: Biosynthesis, Chemistry and Biological Functions. Journal of Chemical and Pharmaceutical Research, 9, 190-200.

[11] Hikal, W.M. and Said-Al Ahl, H.A.H. (2017) Anti-Cryptosporidium Activity of Essential Oil: A Review. American Journal of Food Science and Health, 3, 35-40.

[12] Hikal, W.M. and Said-Al Ahl, H.A.H. (2017) Anti-Leishmanial Activity of Hyssopus officinalis. A Review. International Journal of Environmental Planning and Management, 3, 10-15.

[13] Hikal, W.M. and Said-Al Ahl, H.A.H. (2017) Food Related Parasitic Infection: A Review. American Journal of Food Science and Health, 3, 30-34. https://doi.org/10.1080/23312025.2017.1404274

[14] Hikal, W.M. and Said-Al Ahl, H.A.H. (2019) Influence of Plectranthus amboinicus Essential Oil on Potentially Pathogenic Acanthamoeba Isolated from Water Tanks in Tabuk, Saudi Arabia. Ecology, Environment \& Conservation, 25, 1137-1145.

[15] Said-Al Ahl, H.A.H., Hikal, W.M. and Tkachenko, K.G. (2017) Essential Oils with Potential as Insecticidal Agents: A Review. International Journal of Environmental Planning and Management, 3, 23-33.

[16] Torres-Martínez, R., García-Rodríguez, Y.M., Ríos-Chávez, P., Saavedra-Molina, A., López-Meza, J.E., Ochoa-Zarzosa, A. and Garciglia, R.S. (2018) Antioxidant Activity of the Essential Oil and Its Major Terpenes of Satureja macrostema (Moc. and Sessé ex Benth.) Briq. Pharmacognosy Magazine, 13, S875-S880.

[17] Force, M., Sparks, W.S. and Ronzio, R.A. (2000) Inhibition of Enteric Parasites by Emulsified Oil of Oregano In Vivo. Phytotherapy Research, 14, 213-214. https://doi.org/10.1002/(SICI)1099-1573(200005)14:3<213::AID-PTR583>3.0.CO;2$\underline{\mathrm{U}}$

[18] Giannenas, I., Florou-Paneri, P., Papazahariadou, M., Christaki, E., Botsoglou, N.A. and Spais, A.B. (2003) Dietary Oregano Essential Oil Supplementation on Performance of Broilers Challenged with Eimeria tenella. Archives of Animal Nutrition, 57, 99-106. https://doi.org/10.1080/0003942031000107299

[19] Veal, L. (1996) The Potential Effectiveness of Essential Oils as a Treatment for Head Lice, Pediculus humanus capitis. Complementary Therapies in Nursing \& Midwifery, 2, 97-101. https://doi.org/10.1016/S1353-6117(96)80083-7

[20] Behnia, M., Haghighi, A., Komeylizadeh, H., Tabaei, S. and Abadi, A. (2008) Inhibitory Effects of Iranian Thymus vulgaris Extracts on In Vitro Growth of Entamoeba histolytica. Korean Journal of Parasitology, 46, 153-156. https://doi.org/10.3347/kjp.2008.46.3.153

[21] Goodner, K., Mahattanatawee, K., Plotto, A., Sotomayor, J. and Jordan, M. (2006) Aromatic Profiles of Thymus hyemalis and Spanish T. vulgaris Essential Oils by 
GC-MS/GC-O. Industrial Crops and Products, 24, 264-268.

https://doi.org/10.1016/j.indcrop.2006.06.006

[22] Said-Al Ahl, H.A.H., Sabra, A.S., Alataway, A., Astatkie, T., Mahmoud, A.A. and Bloem, E. (2019) Biomass Production and Essential Oil Composition of Thymus vulgaris in Response to Water Stress and Harvest Time. Journal of Essential Oil Research, 31, 63-68. https://doi.org/10.1080/10412905.2018.1518794

[23] Mseddi, K., Alimi, F., Noumi, E., Veettil, V.N., Deshpande, S., Adnan, M., Hamdi, A., Elkahoui, S., Alghamdi, A., Kadri, A., Patel, M. and Snoussi, M. (2020) Thymus musilii Velen. as a Promising Source of Potent Bioactive Compounds with Its Pharmacological Properties: In Vitro and in Silico Analysis. Arabian Journal of Chemistry, 13, 6782-6801. https://doi.org/10.1016/j.arabjc.2020.06.032

[24] Rota, M.C., Herrera, A., Martínez, R.M., Sotomayor, J.A. and Jordán, M.J. (2008) Antimicrobial Activity and Chemical Composition of Thymus vulgaris, Thymus zygis and Thymus hyemalis Essential Oils. Food Control, 19, 681-687. https://doi.org/10.1016/j.foodcont.2007.07.007

[25] Khadir, A., Sobeh, M., Gad, H., Benbelaid, F., Bendahou, M., Peixoto, H., Sporer, F., Ashour, M.L. and Wink, M. (2016) Chemical Composition and Biological Activity of the Essential Oil from Thymus lanceolatus. Zeitschriftfür Naturforschung C, 71, 155-163. https://doi.org/10.1515/znc-2016-0005

[26] Bistgani, Z.E., Siadat, S.A., Bakhshandeh, A., Pirbalouti, A.G., Hashemi, M., Maggi, F. and Morshedloo, M.R. (2018) Application of Combined Fertilizers Improves Biomass, Essential Oil Yield, Aroma Profile, and Antioxidant Properties of Thymus daenensis Celak. Industrial Crops and Products, 121, 434-440. https://doi.org/10.1016/j.indcrop.2018.05.048

[27] Goudjil, M.B., Zighmi, S., Hamada, D., Mahcene, Z., Bencheikh, S. and Ladjel, S. (2020) Biological Activities of Essential Oils Extracted from Thymus capitatus (Lamiaceae). South African Journal of Botany, 128, 274-282.

https://doi.org/10.1016/j.sajb.2019.11.020

[28] Boubaker, H., Karim, H., El Hamdaoui, A., Msanda, F., Leach, D., Bombarda, I., Vanloot, P., Abbad, A., Boudyach, E.H. and Ben Aoumar, A. (2016) Chemical Characterization and Antifungal Activities of Four Thymus Species Essential Oils against Postharvest Fungal Pathogens of Citrus. Industrial Crops and Products, 86, 95-101. https://doi.org/10.1016/j.indcrop.2016.03.036

[29] Verma, R.S., Verma, R.K., Chauhan, A. and Yadav, A.K. (2011) Seasonal Variation in Essential Oil Content and Composition of Thyme, Thymus serpyllum L. Cultivated in Uttarakhand Hills. Indian Journal of Pharmaceutical Sciences, 73, 233-235. https://doi.org/10.4103/0250-474X.91570

[30] Pavela, R., Bartolucci, F., Desneux, N., Lavoir, A., Canale, A., Maggi, F. and Benelli, G. (2019) Chemical Profiles and Insecticidal Efficacy of the Essential Oils from Four Thymus Taxa Growing in Central-Southern Italy. Industrial Crops and Products, 138, Article ID: 111460. https://doi.org/10.1016/j.indcrop.2019.06.023

[31] Jamali, C.A., Kasrati, A., Fadli, M., Hassani, L., Leach, D. and Abbad, A. (2017) Synergistic Effects of Three Moroccan Thyme Essential Oils with Antibiotic Cefixime. Phytothérapie. https://doi.org/10.1007/s10298-017-1107-2

[32] Lemrhari, A., Zouhair, R., Elidrissi, M., Amechrouq, A., Elhourri, M. and El Kahkahi, R. (2015) Chemical Composition and Differentiation of Essential Oils of Morrocco's Different Varieties of Thyme. Global Journal of Pure and Applied Chemistry Research, 3, 24-34.

[33] Jaafari, A., Mouse, H.A., Rakib, E., M’barek, L.A., Tilaoui, M., Benbakhta, C., Boulli, 
A., Abbad, A. and Zyad, A. (2007) Chemical Composition and Antitumor Activity of Different Wild Varieties of Moroccan Thyme. Brazilian Journal of Pharmacognosy, 17, 477-491. https://doi.org/10.1590/S0102-695X2007000400002

[34] Mattarelli, P., Epifano, F., Minardi, P., Di Vito, M., Modesto, M., Barbanti, L. and Bellardi, M.G. (2017) Chemical Composition and Antimicrobial Activity of Essential Oils from Aerial Parts of Monarda didyma and Monarda fistulosa Cultivated in Italy. Journal of Essential Oil Bearing Plants, 20, 76-86.

https://doi.org/10.1080/0972060X.2016.1278184

[35] Shen, Q., Zhou, W., Li, H., Hu, L. and Mo, H. (2016) ROS Involves the Fungicidal Actions of Thymol against Spores of Aspergillus flavus via the Induction of Nitric Oxide. PLOS ONE, 11, e0155647. https://doi.org/10.1371/journal.pone.0155647

[36] Singh, A., Chaudhari, A.K., Das, S. and Dubey, N.K. (2020) Nanoencapsulated Monarda citriodora Cerv. ex Lag. Essential Oil as Potential Antifungal and Antiaflatoxigenic Agent against Deterioration of Stored Functional Foods. Journal of Food Science and Technology, 57, 2863-2876.

https://doi.org/10.1007/s13197-020-04318-4

[37] Tabanca, N., Bernier, U.R., Ali, A., Wang, M., Demirci, B., Blythe, E.K. and Khan, I.A. (2013) Bioassay-Guided Investigation of Two Monarda Essential Oils as Repellents of Yellow Fever Mosquito Aedes aegypti. Journal of Agricultural Food Chemistry, 61, 8573-8580. https://doi.org/10.1021/jf402182h

[38] Morshedloo, M.R., Craker, L.E., Salami, A., Nazeri, V., Sang, H. and Maggi, F. (2017) Effect of Prolonged Water Stress on Essential Oil Content, Compositions and Gene Expression Patterns of Mono- and Sesquiterpene Synthesis in Two Oregano (Origanum vulgare L.) Subspecies. Plant Physiology and Biochemistry, 111, 119-128. https://doi.org/10.1016/j.plaphy.2016.11.023

[39] Shiyab, S., Shatnawi, M., Shibli, R., Al-Zweiri, M., Akash, M. and Aburijai, T. (2012) Influence of Developmental Stage on Yield and Composition of Origanum syriacum L. Oil by Multivariate Analysis. Journal of Medicinal Plants Research, 6, 2985-2994. https://doi.org/10.5897/JMPR11.1368

[40] Zeroual, A., Sakar, E., Eloutassi, N., Mahjoubi, F., Chaouch, M. and Chaqroune, A. (2021) Phytochemical Profiling of Essential Oils Isolated Using Hydrodistillation and Microwave Methods and Characterization of Some Nutrients in Origanum compactum Benth from Central-Northern Morocco. Biointerface Research in Applied Chemistry, 11, 9358-9371. https://doi.org/10.33263/BRIAC112.93589371

[41] Sabra, A.S., Astatkie, T., Alataway, A., Mahmoud, A.A., Gendy, A.S.H., Said-Al Ahl, H.A.H. and Tkachenko, K.G. (2018) Response of Biomass Development, Essential Oil, and Composition of Plectranthus amboinicus (Lour.) Spreng. to Irrigation Frequency and Harvest Time. Chemistry \& Biodiversity, 15, e1800005.

https://doi.org/10.1002/cbdv.201800005

[42] Sany, H., Alharbi, B.M., Almutairi, K.A., Said-Al Ahl, H.A.H., Mauro, R.P. and Astatkie, T. (2020) Effects of $\mathrm{NaCl}$ on Growth, Essential Oil and Chemical Composition of Plectranthus amboinicus. Plant Archives, 20, 2471-2477.

[43] Mahmoud, A.A., Gendy, A.S.H., Said-Al Ahl, H.A.H., Grulovad, D., Astatkiee, T. and Abdelrazik, T.M. (2018) Impacts of Harvest Time and Water Stress on the Growth and Essential Oil Components of Horehound (Marrubium vulgare). Scientia Horticulturae, 232, 139-144. https://doi.org/10.1016/j.scienta.2018.01.004

[44] Benelli, G., Maggi, F., Petrelli, R., Canale, A., Nicoletti, M., Rakotosaona, R. and Rasoanaivo, P. (2017) Not Ordinary Antimalarial Drugs: Madagascar Plant Decoctions Potentiating the Chloroquine Action against Plasmodium Parasites. Industrial 
Crops and Products, 103, 19-38. https://doi.org/10.1016/j.indcrop.2017.03.032

[45] Sefidkon, F. and Jamzad, Z. (2005) Chemical Composition of the Essential Oil of Three Iranian Satureja Species ( $S$. mutica, S. macrantha and $S$. intermedia). Food Chemistry, 91, 1-4. https://doi.org/10.1016/j.foodchem.2004.01.027

[46] Sefidkon, F., Jamzad, Z. and Mirza, M. (2004) Chemical Variation in the Essential Oil of Satureja sahendica from Iran. Food Chemistry, 88, 325-328. https://doi.org/10.1016/j.foodchem.2003.12.044

[47] Karimi, A., Krähmer, A., Herwig, N., Schulz, H., Hadian, J. and Meiners, T. (2020) Variation of Secondary Metabolite Profile of Zataria multiflora Boiss. Populations Linked to Geographic, Climatic, and Edaphic Factors. Frontiers in Plant Science, 11, 969. https://doi.org/10.3389/fpls.2020.00969

[48] Baser, K.H.C. and Tümen, G. (1994) Composition of the Essential Oil of Lagoecia cuminoides L. from Turkey. Journal of Essential Oil Research, 6, 545-546. https://doi.org/10.1080/10412905.1994.9698448

[49] Bassolé, I.H., Lamien-Meda, A., Bayala, B., Tirogo, S., Franz, C., Novak, J. and Dicko, M.H. (2010) Composition and Antimicrobial Activities of Lippia multiflora Moldenke, Mentha piperita L. and Ocimum basilicum L. Essential Oils and Their Major Monoterpene Alcohols Alone and in Combination. Molecules, 15, 7825-7839. https://doi.org/10.3390/molecules 15117825

[50] Melo, C.R., Picanço, M.C., Santos, A.A., Santos, I.B., Pimentel, M.F., Santos, A.C.C., Blank, A.F., Araujo, A.P.A., Cristaldo, P.F. and Baccia, L. (2018) Toxicity of Essential Oils of Lippia gracilis Chemotypes and Their Major Compounds on Diaphania hyalinata and Non-Target Species. Crop Protection, 104, 47-51.

https://doi.org/10.1016/j.cropro.2017.10.013

[51] Saraiva, A.G.Q., Saraiva, G.D., Albuquerque, R.L., Nogueira, C.E.S., Teixeira, A.M.R., Lima, L.B., Cruz, B.G. and de Sousa, F.F. (2020) Chemical Analysis and Vibrational Spectroscopy Study of Essential Oils from Lippia sidoides and of Its Major Constituent. Vibrational Spectroscopy, 110, Article ID: 103111. https://doi.org/10.1016/j.vibspec.2020.103111

[52] Dheer, J.D., Singh, D., Kumar, G., Karnatak, M., Chandra, S., Verma, V.P. and Shankar, R. (2019) Thymol Chemistry: A Medicinal Toolbox. Current Bioactive Compounds, 15, 454-474. https://doi.org/10.2174/1573407214666180503120222

[53] Novy, P., Davidova, H., Serrano-Rojero, C.S., Rondevaldova, J., Pulkrabek, J. and Kokoska, L. (2015) Composition and Antimicrobial Activity of Euphrasia rostkoviana Hayne Essential Oil. Evidence-Based Complementary and Alternative Medicine, 2015, Article ID: 734101. https://doi.org/10.1155/2015/734101

[54] Gavliakova, S., Biringerova, Z., Buday, T., Brozmanova, M., Calkovsky, V., Poliacek, I. and Plevkova, J. (2013) Antitussive Effects of Nasal Thymol Challenges in Healthy Volunteers. Respiratory Physiology \& Neurobiology, 187, 104-107. https://doi.org/10.1016/j.resp.2013.02.011

[55] Asadbegi, M., Yaghmaei, P., Salehi, I., Komaki, A. and Ebrahim-Habibi, A. (2017) Investigation of Thymol Effect on Learning and Memory Impairment Induced by Intrahippocampal Injection of Amyloid Beta Peptide in High Fat Diet-Fed Rats. Metabolic Brain Disease, 32, 827-839. https://doi.org/10.1007/s11011-017-9960-0

[56] Yu, Y.M., Chao, T.Y., Chang, W.C., Chang, M.J. and Lee, M.F. (2016) Thymol Reduces Oxidative Stress, Aortic Intimal Thickening and Inflammation-Related Gene Expression in Hyperlipidemic Rabbits. Journal of Food and Drug Analysis, 24, 556-563. https://doi.org/10.1016/j.jfda.2016.02.004

[57] Salehi, B., Mishra, A.P., Shukla, I., Sharifi-Rad, M., Contreras, M.M., Segu- 
ra-Carretero, A., Fathi, H., Nasrabadi, N.N., Kobarfard, F. and Sharifi-Rad, J. (2018) Thymol, Thyme, and Other Plant Sources: Health and Potential Uses. Phytotherapy Research, 32, 1688-1706. https://doi.org/10.1002/ptr.6109

[58] Hashemipour, H., Kermanshahi, H., Golian, A. and Veldkamp, T. (2013) Effect of Thymol and Carvacrol Feed Supplementation on Performance, Antioxidant Enzyme Activities, Fatty Acid Composition, Digestive Enzyme Activities, and Immune Response in Broiler Chickens. Poultry Science, 92, 2059-2069.

https://doi.org/10.3382/ps.2012-02685

[59] Tisser, R. and Young, R. (2014) Essential Oil Safety (Second Edition). A Guide for Health Care Professionals. Chapter 3 Natural Products. 71-123.

[60] Wink, M. (2008) Evolutionary Advantage and Molecular Modes of Action of Multi-Component Mixtures Used in Phytomedicine. Current Drug Metabolism, 10, 996-1009. https://doi.org/10.2174/138920008786927794

[61] WHO (2020) Chagas Disease (American Trypanosomiasis). World Health Organization and United Nations Children's Fund, Geneva.

[62] Santoro, G., Graças Cardoso, M., Guimarães, L.G.L., Salgado, A.P.S.P., Menna-Barretp, R.S. and Soares, M.J. (2007) Effect of Oregano (Origanum vulgare L.) and Thyme (Thymus vulgaris L.) Essential Oils on Trypanosoma cruzi (Protozoa: Kinetoplastida) Growth and Ultrastructure. Parasitology Research, 100, 783-790. https://doi.org/10.1007/s00436-006-0326-5

[63] Escobar, P., Leal, S.M., Herrera, L.V., Martinez, J.R. and Stashenko, E. (2010) Chemical Composition and Antiprotozoal Activities of Colombian Lippia spp Essential Oils and Their Major Components. The Memórias do Instituto Oswaldo Cruz, 105, 184-190. https://doi.org/10.1590/S0074-02762010000200013

[64] Borges, A.R., Aires, J.R., Higino, T.M., Medeiros, M.C.F., Citó, A.M.G.L., Lopes, J.A.D. and Figueiredo, R.C.B.Q. (2012) Trypanocidal and Cytotoxic Activities of Essential Oils from Medicinal Plants of Northeast of Brazil. Expermintal Parasitology, 132, 123-138. https://doi.org/10.1016/j.exppara.2012.06.003

[65] Juan, R.A., Olga, P.A. and Mirian, P.P. (2015) Chemical Composition and Anti-Trypanosoma cruzi Effect of Thymus vulgaris L. (Thyme) Essential Oil and Its Main Component, Thymol, in Mice. The Journal of Pharmacy and Pharmacology, 2, 21-27.

[66] WHO (2020) Trypanosomiasis, Human African (Sleeping Sickness). World Health Organization and United Nations Children's Fund, Geneva.

[67] Costa, S., Cavadas, C., Cavaleiro, C., Salgueiro, L. and do Céu Sousa, M. (2018) In Vitro Susceptibility of Trypanosoma brucei brucei to Selected Essential Oils and Their Major Components. Experimental Parasitology, 190, 34-40.

https://doi.org/10.1016/j.exppara.2018.05.002

[68] Kpoviessi, B.G.H.K., Kpoviessi, S.D.S., Ladekan, E.Y., Gbaguidi, F., Frédérich, M., Moudachirou, M., Quetin-Leclercq, J., Accrombessi, G.C. and Bero, J. (2014) In Vitro Antitrypanosomal and Antiplasmodial Activities of Crude Extracts and Essential Oils of Ocimum gratissimum Linn from Benin and Influence of Vegetative Stage. Journal of Ethnopharmacology, 155, 1417-1423. https://doi.org/10.1016/j.jep.2014.07.014

[69] Nibret, E. and Wink, M. (2010) Trypanocidal and Antileukaemic Effects of the Essential Oils of Hagenia abyssinica, Leonotis ocymifolia, Moringa stenopetala, and Their Main Individual Constituents. Phytomedicine, 17, 911-920. https://doi.org/10.1016/j.phymed.2010.02.009

[70] Tasdemir, D., Kaiser, M., Demirci, B., Demirci, F. and Baser, K.H.C. (2019) Anti- 
protozoal Activity of Turkish Origanum onites Essential Oil and Its Components. Molecules, 24, 4421. https://doi.org/10.3390/molecules24234421

[71] Escobar, P., Herrera, L.V., Leal, S.M., Durán, C. and Stashenko, E. (2009) Composiciónquímica y actividad anti-tripanosomal de aceites esenciales obtenidos de $\mathrm{Ta}$ getes (Fam. Asteraceae), recolectadosen Colombia. Revista Salud UIS, 41, 280-286.

[72] McCarthy, S.M. and Davis, C.D. (2003) Prooxidant Diet Provides Protection during Murine Infection with Toxoplasma gondii. Journal of Parasitology, 89, 886-894. https://doi.org/10.1645/GE-3032

[73] CDC (2019) Parasites. CDC 24/7: Travelers' Health-Chapter 4: Travel-Related Infectious Diseases. Toxoplasmosis. Centers for Disease Control and Prevention, U.S. Department of Health \& Human Services, Washington DC.

[74] Farsam, H., Amanlou, M., Radpour, M.R., Salehinia, A.N. and Shafiee, A. (2004) Composition of the Essential Oils of Wild and Cultivated Satureja khuzistanica Jamzad from Iran. Flavour and Fragrance Journal, 19, 308-310. https://doi.org/10.1002/ffj.1300

[75] Hadian, J., Mirjalili, M.H., Kanani, M.R., Salehnia, A. and Ganjipoor, P. (2011) Phytochemical and Morphological Characterization of Satureja khuzistanica Jamzad Populations from Iran. Chemistry \& Biodiversity, 8, 902-915. https://doi.org/10.1002/cbdv.201000249

[76] Mahmoudvand H., Beyranvand, M., Nayebzadeh, H., Fallahi, S., Mirbadie, S.R., Kheirandish, F. and Kayedi, M.H. (2017) Chemical Composition and Prophylactic Effects of Saturja khuzestanica Essential Oil on Acute Toxoplasmosis in Mice. African Journal of Traditional, Complementary and Alternative Medicines, 14, 49-55. https://doi.org/10.21010/ajtcam.v14i5.7

[77] Arfa, A.B., Combes, S., Preziosi-Belloy, L., Gontard, N. and Chalier, P. (2006) Antimicrobial Activity of Carvacrol Related to Its Chemical Structure. Letters in Applied Microbiology, 43, 149-154. https://doi.org/10.1111/j.1472-765X.2006.01938.x

[78] Oliveira, C.B.S., Meurer, Y.S.R., Medeiros, T.L., Pohlit, A.M., Silva, M.V., Mineo, T.W.P. and Andrade-Neto, V.F. (2016) Anti-Toxoplasma Activity of Estragole and Thymol in Murine Models of Congenitial and Noncongenitial Toxoplasmosis. Journal of Parasitology, 102, 369-376. https://doi.org/10.1645/15-848

[79] WHO (2020) Leishmaniasis. World Health Organization and United Nations Children's Fund, Geneva.

[80] Tisserand, R. and Balacs, T. (1995) Essential Oil Safety: A Guide for Health Care Professionals, Churchill Livingstone.

[81] Silva, A.R.S., Scher, R., Santos, F.V., Ferreira, S.R., Cavalcanti, S.C.H., Cristiane, B., Correa, C.B., Bueno, L.L., Alves, R.J., Souza, D.P., Fujiwara, R.T. and Dolabella, S.S. (2017) Leishmanicidal Activity and Structure-Activity Relationships of Essential Oil Constituents. Molecules, 22, 815. https://doi.org/10.3390/molecules22050815

[82] De Melo, J.O., Bitencourt, T.A., Fachin, A.L., Cruz, E.M., de Jesus, H.C., Alves, P.B., de Fátima Arrigoni-Blank, M., de Castro Franca, S., Beleboni, R.O., Fernandes, R.P., et al. (2013) Antidermatophytic and Antileishmanial Activities of Essential Oils from Lippia gracilis Schauer Genotypes. Acta Tropica, 128, 110-115. https://doi.org/10.1016/j.actatropica.2013.06.024

[83] Farias-Junior, P., Rios, M., Moura, T., Almeida, R., Alves, P., Blank, A. and Scher, R. (2012) Leishmanicidal Activity of Carvacrol-Rich Essential Oil from Lippia sidoides Cham. Biological Research, 45, 399-402. https://doi.org/10.4067/S0716-97602012000400012

[84] Xavier, F.J.S., Rodrigues, K.A.F., De Oliveira, R.G., Lima Junior, C.G., Rocha, J.D.C., 
Keesen, T.S.L., De Oliveira, M.R., Silva, F.P.L. and Vasconcellos, M.L.A.A. (2016) Synthesis and in Vitro Anti-Leishmania amazonensis Biological Screening of Morita-Baylis-Hillman Adducts Prepared from Eugenol, Thymol and Carvacrol. Molecules, 21, 1483. https://doi.org/10.3390/molecules21111483

[85] Robledo, S., Osorio, E., Muñoz, D., Jaramillo, L.M., Restrepo, A., Arango, G. and Vélez, I. (2005) In Vitro and In Vivo Cytotoxicities and Antileishmanial Activities of Thymol and Hemisynthetic Derivatives. Antimicrobial Agents and Chemotherapy, 49, 1652-1655. https://doi.org/10.1128/AAC.49.4.1652-1655.2005

[86] Oliveira, V.C.S, Moura, D.M., Lopes, J.A., Andrade, P.P., Silva, N.H. and Figueiredo, R.C. (2009) Effects of Essential Oils from Cymbopogon citratus (DC) Stapf., Lippia sidoides Cham. and Ocimun gratissimum L. on Growth and Ultrastructure of Leishmania chagasi Promastigotes. Parasitology Research, 104, 1053-1059. https://doi.org/10.1007/s00436-008-1288-6

[87] De Medeiros, M., Da Silva, A., Citó, A., Borges, A., De Lima, S., Lopes, A. and Figueiredo, R. (2011) In Vitro Antileishmanial Activity and Cytotoxicity of Essential Oil from Lippia sidoides Cham. Parasitology International, 60, 237-241. https://doi.org/10.1016/j.parint.2011.03.004

[88] Morales, M., Navarro, M.C., Martin, J., Valero, A., Lara, A.M., Barón, S. and Morillas, F. (2009) Activity of Different Monoterpenic Derivatives of Natural Origin against Leishmania infantum Promatisgotes. RevistaIbero-Latinoamericana de Parasitología, 68, 65-72.

[89] De Morais, S.M., Vila-Nova, N.S., Bevilaqua, C.M.L., Rondon, F.C., Lobo, C.H., de Alencar A.N., Moura, A., Sales, A.D., Rodrigues, A.P.R., de Figuereido, J.R., Campello, C.C., Wilson, M.E. and de Andrade, H.F.Jr. (2014) Thymol and Eugenol Derivatives as Potential Antileishmanial Agents. Bioorganic \& Medicinal Chemistry, 22, 6250-6255. https://doi.org/10.1016/j.bmc.2014.08.020

[90] Youssefi, M.R., Moghaddas, E., Tabari, M.A., Moghadamnia, A.A., Hosseini, S.M., Farash, B.R.H., Ebrahimi, M.A., Mousavi, N.N., Fata, A., Maggi, F., Petrelli, R., Dall'Acqua, S., Benelli, G. and Sut, S. (2019) In Vitro and in Vivo Effectiveness of Carvacrol, Thymol and Linalool against Leishmania infantum. Molecules, 24, 2072. https://doi.org/10.3390/molecules24112072

[91] Jain, K. and Jain, N.K. (2013) Novel Therapeutic Strategies for Treatment of Visceral Leishmaniasis. Drug Discovery Today, 18, 1272-1281.

https://doi.org/10.1016/j.drudis.2013.08.005

[92] Mohammadpour, G., Marzony, E.T. and Farahmand, M. (2012) Evaluation of the Anti-Leishmania Major Activity of Satureja bakhtiarica Essential Oil in Vitro. Natural Product Communications, 7, 133-136. https://doi.org/10.1177/1934578X1200700142

[93] Costa, J.G.M., Rodrigues, F.F.G., Angé, E.C., Pereira, C.K.B., Souza, E.O., Caldas, G.F.R., Silva, M.R., Santos, N.K.A., Mota, M.L. and Santos, P.F. (2008) Composiçãoquímica e avaliação da atividade antibacteriana e toxicidade do óleoessencial de Croton zehntneri (variedade estragol). Brazilian Journal of Pharmacognosy, 18, 583-586. https://doi.org/10.1590/S0102-695X2008000400015

[94] Medeiros, M., DaSilva, A.C., Cito, A.M., Borges, A.R., De Lima, S.G., Lopes, J.A.D. and Figueiredo, R.C.B.Q. (2011) In Vitro Antileishmanial Activity and Cytotoxicity of Essential Oil from Lippia sidoides Cham. Parasitology International, 60, 237-241. https://doi.org/10.1016/j.parint.2011.03.004

[95] CDC (2019) Parasites. CDC 24/7: Travelers' Health-Chapter 4: Travel-Related Infectious Diseases. Malarial. Centers for Disease Control and Prevention, U.S. Department of Health \& Human Services, Washington DC. 
[96] Mota, M.L., Lobo, L.T.C., Costa, J.M.G., Costa, L.S., Rocha, H.A.O., Rocha, Silva, L.F., Pohlit, A.M. and Andrade-Neto, V.F. (2012) In Vitro and in Vivo Antimalarial Activity of Essential Oils and Chemical Components from Three Medicinal Plants Found in Northeastern Brazil. Planta Medica, 78, 658-664. https://doi.org/10.1055/s-0031-1298333

[97] Fujisaki, R., Kamei, K., Yamamura, M., Nishiya, H., Inouye, S., Takahashi, M. and Abe, S. (2012) In Vitro and In Vivo Anti-Plasmodial Activity of Essential Oils, Including Hinokitiol. Southeast Asian Journal of Tropical Medicine and Public Health, 43, 270-279.

[98] Dorman, H.J.D. and Deans, S.G. (2000) Antimicrobial Agents from Plants: Antibacterial Activity of Plant Volatile Oils. Journal of Applied Microbiology, 88, 308-316. https://doi.org/10.1046/j.1365-2672.2000.00969.x

[99] Ultee, A., Bennik, M.H.J. and Moezelaar, R. (2002) The Phenolic Hydroxyl Group of Carvacrol Is Essential for Action against the Foodborne Pathogen Bacillus cereus. Applied and Environmental Microbiology, 68, 1561-1568. https://doi.org/10.1128/AEM.68.4.1561-1568.2002

[100] Dell'Agli, M., Sanna, C., Rubiolo, P., Basilico, N., Colombo, E., Scaltrito, M.M., Ndiath, M.O., Maccarone, L., Taramelli, D., Carlo Bicchi, C., Ballero, M. and Bosisio, E. (2012) Anti-Plasmodial Andinsecticidal Activities of the Essential Oils of Aromatic Plants Growing in the Mediterranean Area. Malaria Journal, 11, 219. https://doi.org/10.1186/1475-2875-11-219

[101] El Babili, F., Bouajila, J., Souchard, J.P., Bertrand, C., Bellvert, F., Fouraste, I., Moulis, C. and Valentin, A. (2011) Oregano: Chemical Analysis and Evaluation of Its anti-Malarial, Antioxidant, and Cytotoxic Activities. Journal of Food Science, 76, C512-C518. https://doi.org/10.1111/j.1750-3841.2011.02109.x

[102] Amer, A. and Mehlohrn, H. (2006) Repellency Effect of Forty-One Essential Oils against Aedes, Anopheles, and Culex Mosquitoes. Parasitology Research, 99, 478-490. https://doi.org/10.1007/s00436-006-0184-1

[103] Barnard, D.R. (1999) Repellency of Essential Oils to Mosquitoes (Diptera: Culicidae). Journal of Medical Entomology, 36, 625-629. https://doi.org/10.1093/jmedent/36.5.625

[104] Guanmin, F., Ling, Y. and Yunhe, C. (2005) Anophelifuge Essence Combination with Medicinal Herb Type Odor and Preparation Method Thereof. CN1250089C, China.

[105] Amer, A. and Mehlhorn, H. (2006) Larvicidal Effects of Various Essential Oils against Aedes, Anopheles, and Culex Larvae (Diptera, Culicidae). Parasitology Research, 99, 466-472. https://doi.org/10.1007/s00436-006-0182-3

[106] Massebo, F., Tadesse, M., Bekele, T., Balkew, M. and Gebre-Michael, T. (2009) Evaluation on Larvicidal Effects of Essential Oils of Some Local Plants against Anopheles arabiensis Patton and Aedes aegypty Linnaeus (Diptera, Culicidae) in Ethiopia. African Journal of Biotechnology, 8, 4183-4188.

[107] Tchoumbougnang, F., Dongmo, P.M.Z., Sameza, M.L., Mbanjo, E.G.N., Fotso, G.B.T., Zollo, P.H. and Menut, C. (2009) Larvicidal Activity against Anopheles gambiae Giles and Chemical Composition of Essential Oils from Four Plants Cultivated in Cameroon. Biotechnologie, Agronomie, Societeet Environnement, 13, 77-84.

[108] CDC (2019) Parasites. CDC 24/7: Travelers' Health-Chapter 4: Travel-Related Infectious Diseases. Giardiasis. Centers for Disease Control and Prevention, U.S. Department of Health \& Human Services, Washington DC. 
[109] Machado, M., Cavaleiro, C., Salgueiro, L., Silca, P.J., Custodio, J.B. and Sousa, M.C. (2008) Anti-Giardial Activity of Carvacrol, Thymol and Eugenol. 18th European Society of Clinical Microbiology and Infectious Diseases, Barcelona, 19-22 April 2008.

[110] Machado, M., Dinis, A.M., Salgueiro, L., Cavaleiro, C., Custodio, J.B. and Sousa, M.C. (2010) Anti-Giardia Activity of Phenolic-Rich Essential Oils of Thymbra capitata, Origanum virens, Thymus zygis subsp. Sylvestris Chemotype Thymol, and Lippia graveolens on Trophozoites Growth, Viability, Adherence, and Ultrastructure. Parasitology Research, 106, 1205-1215. https://doi.org/10.1007/s00436-010-1800-7

[111] CDC (2019) Parasites. CDC 24/7: Travelers' Health-Chapter 4: Travel-Related Infectious Diseases. Cryptosporidiosis. Centers for Disease Control and Prevention, U.S. Department of Health \& Human Services, Washington DC.

[112] Tanghort, M., Chefchaou, H., Mzabi, A., Moussa, H., Chami, N., Chami, F. and Remmal A. (2019) Oocysticidal Effect of Essential Oils (EOs) and Their Major Components on Cryptosporidium baileyi and Cryptosporidium galli. International Journal of Poultry Science, 18, 475-482. https://doi.org/10.3923/ijps.2019.475.482

[113] USDA (2018) Study Shows Oregano Essential Oil's Ability to Reduce Parasite Infectivity, Thursday, July 12, 2018.

[114] CDC (2019) Parasites. CDC 24/7: Travelers' Health-Chapter 4: Travel-Related Infectious Diseases. Helminths, Soil-Transmitted. Centers for Disease Control and Prevention, U.S. Department of Health \& Human Services, Washington DC.

[115] Kaplan, R.M., Storey, M.E., Vidyashankar, A.N., Bissinger, B.W., Mitchell, S.M., Howell, S.B., Mason, E.M., Leed, M.D., Pedrosod, A.A., Akashee, A. and Skrypec, D.J. (2014) Antiparasitic Efficacy of a Novel Plant-Based Functional Food Using an Ascaris suum Model in Pigs. Acta Tropica, 139, 15-22. https://doi.org/10.1016/j.actatropica.2014.06.008

[116] CDC (2012) Parasites. CDC 24/7: Parasites-Echinococcosis. Centers for Disease Control and Prevention, U.S. Department of Health \& Human Services, Washington DC.

[117] Albani, C.M., Pensel, P.E., Elissondo, N., Gambino, G. and Elissondo, M.C. (2015) In Vivo Activity of Albendazole in Combination with Thymol against Echinococcus multilocularis. Veterinary Parasitology, 212, 193-199.

https://doi.org/10.1016/j.vetpar.2015.06.030

[118] Elissondo, M.C., Albani, C.M., Gende, L., Eguaras, G. and Denegri, M. (2008) Efficacy of Thymol against Echinococcus granulosus Protoscoleces. Parasitology International, 57, 185-190. https://doi.org/10.1016/j.parint.2007.12.005

[119] Moazeni, M., Saharkhiz, M.J. and Hosseini, A.A. (2012) In Vitro Lethal Effect of Ajowan (Trachyspermum ammi L.) Essential Oil on Hydatid Cyst Protoscoleces. Veterinary Parasitology, 187, 203-208. https://doi.org/10.1016/j.vetpar.2011.12.025

[120] Elissondo, M.C., Pensel, P.E. and Denegri, G.M. (2013) Could Thymol Have Effectiveness on Scolices and Germinal Layerof hydatid Cysts? Acta Tropica, 125, 251-257. https://doi.org/10.1016/j.actatropica.2012.12.007

[121] Albanese, A., Elissondo, M.C., Gende, L., Eguaras, M. and Denegri, G.M. (2009) Echinococcus granulosus. in Vitro Efficacy of Rosmarinus officinalis Essential Oil on Protoscoleces. International Journal of Essential Oil Therapeutics, 3, 69-75.

[122] Maggiore, M.A., Albanese, A.A., Gende, L.B., Eguaras, M.J., Denegri, G.M. and Elissondo, M.C. (2012) Anthelmintic Effect of Mentha spp. Essential Oils on Echinococcus granulosus Protoscoleces and Metacestodes. Parasitology Research, 110, 
1103-1112. https://doi.org/10.1007/s00436-011-2595-x

[123] Taran, M., Azizi, E., Shikhvaisi, A. and Asadi, N. (2009) The Anthelmintic Effect of Pistacia khinjuk against Protoscoleces of Echinococcus granulosus. World Journal of Zoology, 4, 291-295.

[124] Pensel, P.E., Maggiore, M.A., Gende, L.B., Eguaras, M.J., Denegri, M.G. and Elissondo, M.C. (2014) Efficacy of Essential Oils of Thymus vulgaris and Origanum vulgare on Echinococcus granulosus. Interdisciplinary Perspectives on Infectious Diseases, 2014, Article ID: 693289. https://doi.org/10.1155/2014/693289

[125] Pan, S.S., Bera, A.K., Sreevatsava, V., Bandyopadhyay, S., Chaudhuri, D., Kumar, S., Rana, T., Das, S., Das, S.K., Suryanaryana, V.V., Norjit Singh, M. and Bhattacharya, D. (2012) In Vitro Assessment of Praziquantel and a Novel Nanomaterial against Protoscoleces of Echinococcus granulosus. Journal of Helminthology, 86, 26-29. https://doi.org/10.1017/S0022149X10000908

[126] Chitko-McKown, C.G. and Leymaster, K.A. (2009) Associations between Haemonchus contortus Infection in Lambs and Blood Traits. Proceeding of the 90 th Conference of Research Workers in Animal Diseases, Chicago, 5-8 December 2009, 112.

[127] Indiana Animal Disease Diagnostic Laboratory Newsletter (2011) Haemonchus Contortus in Sheep and Goats: An Insidious Killer. Animal Disease Diagnostic Laboratory Is Located on Purdue University's West Lafayette Campus.

[128] Selemon, M. (2018) Review on Control of Haemonchus contortus in Sheep and Goat. Journal of Veterinary Medicine and Research, 5, 1139.

[129] Wallera, P.J. and Chandrawathani, P.B. (2005) Haemonchus contortus. Parasite Problem No. 1 from Tropics-Polar Circle. Problems and Prospects for Control Based on Epidemiology. Tropical Biomedicine, 22, 131-137.

[130] Ceï, W., Mahieu, M., Philibert, L., Arquet, R., Alexandre, G., Mandonnet, N. and Bambou, J.C. (2015) Impact of the Post-Weaning Parasitism History on an Experimental Haemonchus contortus Infection in Creole Goat Kids. Veterinary Parasitology, 207, 166-169. https://doi.org/10.1016/j.vetpar.2014.11.010

[131] Ferreira, L.E., Benincasa, B.I., Fachin, A.L., França, S.C., Continia, S.S.H.T., Chagas, A.C.S. and Beleboni, R.O. (2016) Thymus vulgaris L. Essential Oil and Its Main Component Thymol: Anthelmintic Effects against Haemonchus contortus from Sheep. Veterinary Parasitology, 228, 70-76. https://doi.org/10.1016/j.vetpar.2016.08.011

[132] André, W.P.P., Cavalcante, G.S., Ribeiro, W.L.C., dos Santos, J.M.L., Macedo, I.T.F., de Paula, H.C.B., de Morais, S.M., de Melo, J.V. and Bevilaqua, C.M.L. (2017 ) Anthelmintic Effect of Thymol and Thymol Acetate on Sheep Gastrointestinal Nematodes and Their Toxicity in Mice. Brazilian Journal of Veterinary Parasitology, 26, 323-330. https://doi.org/10.1590/s1984-29612017056

[133] Peek, H.W. and Landman, W.J.M. (2011) Coccidiosis in Poultry: Anticoccidial Products, Vaccines and Other Prevention Strategies, Veterinary Quarterly, 31, 143-161. https://doi.org/10.1080/01652176.2011.605247

[134] Williams, R.B. (1999) A Compartmentalised Model for the Estimation of the Cost of Coccidiosis to the World's Chicken Production Industry. International Journal for Parasitology, 29, 1209-1229. https://doi.org/10.1016/S0020-7519(99)00086-7

[135] Teichmann, K., Köstelbauer, A., Steiner, T., Giannenas, I., Tontis, D., Papadopoulos, E. and Schatzmayr, G. (2012) Phytogenics to Prevent Chicken Coccidiosis. Planta Medica, 78, PF72. https://doi.org/10.1055/s-0032-1320619 